\title{
METODE SOROGAN SEBAGAI MODEL PEMBERANTASAN BUTA HURUF HIJAIYYAH BAGI IBU-IBU RUMAH TANGGA DI KOTA MALANG
}

\author{
Anita Andriya Ningsih ${ }^{1)}$, Mubasyiroh ${ }^{2)}$, Siti Fatimah ${ }^{3)}$ \\ 1)Fakultas Sains dan Teknologi UIN Maulana Malik Ibrahim Malang. Email: anitaandriyaningsih@uin-malang.ac.id, \\ ${ }^{2)}$ Fakultas Sains dan Teknologi UIN Maulana Malik Ibrahim Malang, Email: Mubasyiroh9@gmail.com, \\ ${ }^{3)}$ Fakultas Ilmu Tarbiyah dan Keguruan UIN Maulana Malik Ibrahim Malang, Email: siti.fatimah@uin-malang.ac.id
}

\begin{abstract}
ABSTRAK
Bagi seorang muslim, kemampuan membaca huruf hijaiyah merupakan hal yang urgent karena Kitab suci umat muslim, yaitu Al-Qur'an ditulis menggunakan bahasa Arab yang hurufhurufnya adalah huruf hijaiyyah. Kegiatan pengabdian kepada masyarakat ini bertujuan untuk memecahkan problem buta huruf hijaiyyah bagi ibu-ibu rumah tangga di Kelurahan Ketawanggede, Kecamatan Lowokwaru, Kota Malang dengan memberikan pelatihan dan pendampingan terhadap mereka dalam mengenal dan membaca huruf hijaiyyah atau ayat-ayat dalam Alqur'an dengan benar sesuai kaidah. Jumlah peserta kegiatan ini adalah sebanyak 60 orang yang dibagi menjadi 3 kelas atau kategori, yaitu a) peserta yang sama sekali belum mengenal huruf hijaiyah, b) peserta yang sudah mengenal huruf hijaiyyah tetapi keliru dalam melafadzkannya, dan c) peserta yang sudah dapat membaca huruf hijaiyyah tetapi masih menemui kekeliruan dalam membaca terutama makharijul huruf dan kaidah-kaidah tajwid. Di antara hasil dari kegiatan pengabdian ini adalah setelah melalui pelatihan dan pendampingan secara intensif menggunakan metode sorogan, peserta mengalami peningkatan kemampuan membaca huruf hijaiyah (pisah dan sambung) dan ayat-ayat dalam Alqur'an.
\end{abstract}

Kata kunci: Melek huruf, hijaiyyah, sorogan, pendampingan intensif.

\section{ABSTRACT}

For a Muslim, the ability to read Hijaiyah letters is important because the holy Book of Muslims, the Qur'an is written by using Arabic language that the letters is a letter Hijaiyyah. This community is aimed to solve hijaiyyah illiteracy problem for housewives in Ketawanggede subdistrict, Lowokwaru subdistrict, Malang City by providing training and mentoring to them in Know and read the letters Hijaiyyah or verses in the Qur'an correctly in accordance with the rules. The number of participants of this activity is as many as 60 people divided into 3 classes or categories, namely a) participants who are not familiar with the letters Hijaiyah, B) Participants who already know the letter Hijaiyyah but erroneous in the pronunciation, and c) participants who Can already read the letter Hijaiyyah but still found confusion in reading mainly Makharijul letters and rules tajwid. Among the results of this devotion is after through training and mentoring intensively using the methods of Sorogan with the forward one by one and then corrected directly by Ustadz and directly in the process of justification, so that through Sorogan method that is more focused and direct evaluation, participants experienced an increase in the ability to read Hijaiyah letters (split and Dial) and verses in the Qur'an.

Keywords: literacy, Hijaiyyah, sorogan, intensive mentoring. 


\section{PENDAHULUAN}

KetawangGede merupakan daerah perkotaan yang ada di wilayah Ketawanggede kecamatan Lowokwaru kota Malang, penduduknya padat dari warga asli ataupun pendatang baik mahasiswa atau yang menetap. Warga asli di Ketawanggede berlatar belakang pendidikan baik, dilihat dari segi formal maupun informal. Mereka mudah mendapatkan pendidikan berkualitas baik dan mengakses ilmu pengetahuan dengan kemajuan teknologi. Wilayah ini juga dekat dengan berbagai akses, diantaranya kampus-kampus ternama juga sekolah-sekolah unggulan di kota Malang. Akan tetapi di sisi lain ada satu permasalahan yang harus segera diselesaikan, yaitu rendahnya tingkat melek huruf Hijaiyyah yang dimiliki oleh kebanyakan ibu-ibu rumah tangga yang ada di wilayah ini.

Berdasarkan hasil wawancara dengan kordinator TPQ At-Taubah, yaitu bapak Bahrun yang beliau juga merangkap sebagai pengajar menjelaskan bahwasannya:

"Disini banyak sekali ibu-ibu yang belum bisa membaca al-qur'an bahkan banyak juga yang belum mengenal huruf hijaiyyah. Program ini sudah 5 tahun berjalan, awal mula ada dari mulut ke mulut ibu-ibu yang mau mengaji saling mengajak belajar bersama, bahkan setiap hari belajarnya. Mereka termotivasi karena anak mereka protes, anaknya bisa ngaji ibunya masak ga bisa ngaji. Begitu ceritanya, Alhamdulillah ini masih ada sampai sekarang dan anggotanya semakin bertambah."

Selain hasil wawancara, tim pengabdi juga melakukan observasi terhadap data-data peserta melek huruf hijaiyyah yang ada di TPQ At-Taubah. Berdasarkan data peserta diperoleh bahwasannya ada penurunan peserta yang belum melek huruf hijaiyyah. Berikut grafik tentang jumlah peserta melek huruf hijaiyyah setiap tahunnya.

Pada gambar 1 jelas sekali bahwasannya semangat ibu-ibu rumah tangga untuk belajar mengaji dan melek huruf hijaiyyah semakin meningkat setiap tahunnya sehingga kegiatan ini harus selalu digalakkan dan dikembangkan dengan berbagai metode cara mengaji berdasarkan kebutuhan peserta.

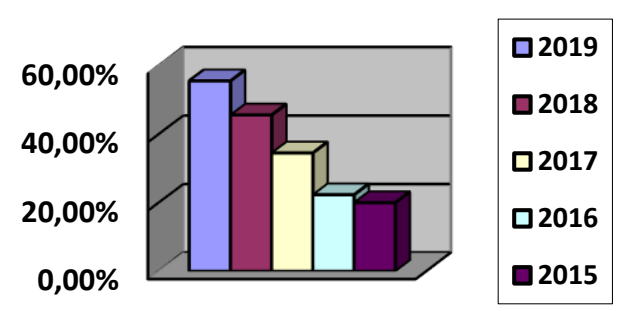

Gambar 1.Jumlah ibu-ibu rumah tangga melek huruf hijaiyyah

Dengan kemajuan teknologi yang serba modern ini, mereka bisa belajar menggunakan media teknologi yang banyak tersedia saat ini, namun hal tersebut belum banyak membuahkan hasil yang maksimal karena ketika mereka mengucapkan atau membaca huruf Hijaiyyah dengan keliru atau kurang tepat, tidak ada yang langsung mengoreksi kekeliruan bacaannya tersebut.

Pembelajaran mengaji yang ada selama ini sudah dilakukan untuk orang dewasa yaitu selalu bebarengan, dengan cara ustadz melafalkan terlebih dahulu setelah itu ditirukan oleh yang lain. Hal ini hasilnya kurang maksimal dan menambah semangat para orang dewasa untuk selalu mengaji, tidak seperti dalam proses pembelajaran menggunakan metode sorogan. Oleh sebab itu perlu adanya program pengabdian kepada masyarakat yang berfokus pada pemberantasan huruf Hijaiyyah dengan metode sorogan ini.

Berdasarkan pada latar belakang yang telah diuraikan tersebut, maka untuk membantu memecahkan problema yang dihadapi oleh kelurahan Ketawanggede kecamatan Lowokwaru kota Malang, Lembaga Penelitian dan Pengabdian Masyarakat (LP2M) Universitas Islam Negeri Maulana Malik Ibrahim Malang memberikan kesempatan kepada para dosen untuk melakukan pengabdian masyarakat pada TPQ At-taubah di Ketawanggede kecamatan 
Lowokwaru kota Malang melalui program UIN Mengabdi 2019.

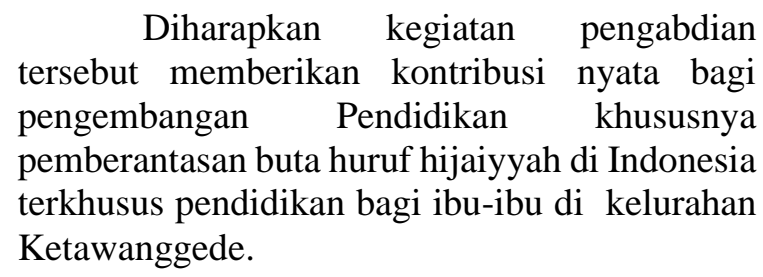

\section{PELAKSANAAN KEGIATAN}

\begin{abstract}
Kegiatan pengabdian kepada masyarakat ini dilakukan sebanyak 6 kali pertemuan, mulai pukul 10:00 - 18:00 WIB dan seminggu dua kali pertemuan setiap hari senin dan kamis. Dalam setiap pertemuan para ibu-ibu yang ikut kegiatan belajar mengaji dibagi menjadi 3 kelompok. Dan masing-masing kelompok ada tutor atau ustadzah yang mendampingi.
\end{abstract}

\section{METODOLOGI PENGABDIAN}

Sesuai dengan tujuan yang ingin dicapai dalam pengabdian "Metode Sorogan Sebagai Model Pemberantasan Buta Huruf Hijaiyyah Bagi Ibu-Ibu Rumah Tangga Di Kelurahan Ketawanggede Kecamatan Lowokwaru Kota Malang" maka tim pengabdian memilih jenis pengabdian berbasis research atau biasa di sebut dengan Community Based Research (CBR) sebagai pendekatan dalam melaksanakan program pengabdian. Pemilihan ini didasarkan pada karakteristik CBR yang memadukan antara kegiatan riset dan pengabdian memberikan penekanan terhadap pelaksanaan pengabdian dengan melibatkan partisipan. Sehingga hasil dari CBR adalah adanya interkorelasi antara peneliti dan partisipan (Strand, Marullo, \& Cutforth, 2003: 56).

Tim pengabdi melakukan identifikasi masalah-masalah yang muncul di masyarakat. Kemudian menentukan masalah yang menjadi target pengabdian. Berdasarkan dialog dengan lurah kepala desa Ketawanggede, diperoleh infromasi beberapa problema yang ada di desa Ketawanggede. Salah satunya kemampuan mengaji para ibu-ibu rumah tangga. Tim pengabdi memilih permasalahan kemampuan mengaji para ibu-ibu rumah tangga sebagai target pengabdian didasarkan pada beberapa alasan yaitu:

a. TPQ At-Taubah merupakan salah satu lembaga atau wadah yang dimiliki oleh Kelurahan Ketawanggede. TPQ ini merupakan hasil inisiatif masyarakat yang perlu mendapatkan suport untuk pengembangannya.

b. Kesadaran masyarakat yang tinggi terhadap pentingnya belajar mengaji alqur'an atau melek huruf hijaiyyah.

Banyak ibu-ibu yang memiliki latarbelakang pendidikan tapi belum bisa mengaji atau melek huruf hijaiyyah sedangkan ibu adalah madrosatul ula untuk anak-anaknya, sehingga ibu juga harus bisa mengaji. Ibu-ibu semangat dan antusias sehingga perlu pembinaan yang fokus.

Berdasarkan pada solusi yang telah dipilih untuk memecahkan masalah di TPQ AtTaubah Ketawanggede, selanjutnya dibuat rencana program metode sorogan sebagai model pemberantasan buta huruf hijaiyyah ibu-ibu rumah tangga. Untuk itu, kegiatan yang dilakukan adalah; Kegiatan pengabdian ini menggunakan metode atau sistem sorogan, yaitu peserta maju satu persatu menghadap tutor atau pengajar untuk membaca materi dari Alqur'an dan rujukan untuk belajar makhorijul huruf dari buku Umi serta ilmu tajwid diberikan oleh tutor. Tutor mengoreksi kesalahan bacaan peserta, kemudian peserta membetulkan bacaan yang telah dikoreksi dan seterusnya. Untuk peserta yang sudah bisa membaca dengan lancar dan benar maka ditingkatkan dengan belajar terjemah dari ayat tersebut disertai dengan asbabun nuzul. Untuk surat yang dibelajari oleh ibu-ibu dimulai dari Juz amma yang lebih mudah dengan asumsi sering didengarkan dari pada surat-surat lain dalam al-qur'an. Setelah juz amma selesai baru belajar ke juz pertama dan seterusnya.

\section{HASIL DAN PEMBAHASAN}


Al-Qur'an merupakan wahyu Allah yang diturunkan kepada Nabi Muhammad melalui malaikat jibril dan yang membacanya adalah suatu ibadah. Umat Islam wajib belajar Al-Qur'an karena merupakan petunjuk bagi manusia untuk memperoleh suatu kehidupan dunia dan akhirat. Namun kenyataannya masih ada masyarakat yang belum bisa membaca Al-Qur'an, yang mana masyarakat masih mementingkan urusan dunia sehingga ia lupa akan mengaji atau membaca Al-Qur'an.

Pada penelitian ini ibu-ibu tidak malu akan belajar Al-Qur'an, walaupun belajar sedikit demi sedikit. Sehingga dibutuhkan usaha untuk meningkatkan kualitas masyarakat dalam belajar Al-Qur'an. Kemampuan membaca AlQur'an dengan benar merupakan target pokok yang harus dicapai. Pelatihan dan pendampingan secara intensif ini dilakukan dengan sistem atau metode sorogan, yaitu peserta maju satu-persatu ke pelatih atau pendamping, dalam hal ini pelaksana kegiatan pengabdian untuk membaca huruf-huruf atau kata-kata atau ayat-ayat pendek dari buku atau Juz 'Amma atau Al-Qur'an.

Di TPQ At-Taubah ini digunakan Buku Membaca Ummi. Pendamping menyimak bacaan dan mengoreksi bacaan yang keliru dengan memberikan contoh bacaan benar dan meminta peserta mengulangi bacaan tersebut sampai benar. Kelompok 1 dan 2 difokuskan pada pengenalan dan cara melafalkan hurufhuruf atau kata-kata bahasa Arab dengan benar. Sedangkan kelompok 3 merupakan kelanjutannya, yaitu difokuskan pada makharijul huruf dan tajwid (hukum tanwin dan nun sukun, ghunnah, mad dan sebagainya).

Dalam sebuah metode pasti ada kekurangan dan kelebihan. diantara kekurangan Metode Sorogan adalah:

1. Terjadi hubungan yang erat dan harmonis antara pengajar dengan murid.

2. Memungkinkan bagi seorang pengajar untuk mengawasi, menilai dan membimbing secara maksimal kemampuan seorang murid dalam membaca.
3. Murid mendapatkan penjelasan yang pasti tanpa harus mereka-reka karena secara langsung dapat terjadi tanya jawab.

4. Pengajar dapat mengetahui secara pasti kualitas yang telah dicapai muridnya.

Sedangkan Kelemahan Metode Sorogan

1. Tidak efesien karena hanya menghadapi beberapa murid (Tidak lebih dari 5 orang), sehingga kalau menghadapi murid yang banyak metode ini kurang begitu tepat.

2. Membuat murid cepat bosan karena metode ini menuntut kesabaran, kerajinan, ketaatan, dan disiplin pribadi. (Dalam Armai, 2002: 151-152)

Pada dasarnya prinsip pengajaran alQur'an bisa dilakukan dengan macam-macam metode diantaranya sorogan atau 'Ardul qira'ah adalah dimana murid membaca di depan guru, sedang guru menyimaknya. Metode ini dikenal dengan juga metode "setoran bacaan". Metode ini diterapkan oleh nabi saw. Bersama malaikat Jibril kala tes bacaan al-Qur'an di bulan Ramadhan. Pada metode ini Guru mengulangngulang bacaan, sedangkan anak atau murid menirukannya kata per kata dan kalimat per kalimat juga secara berulang-ulang hingga terampil dan benar (Dalam Salman, 2004: 81).

Di samping pelatihan dan pendampingan dari tim pelaksana kegiatan pengabdian, untuk memperkaya pengetahuan dan pengalaman para peserta, dihadirkan pula pemateri ahli dalam mengajarkan membaca huruf hijaiyyah, yaitu Bapak Ahmad Paiman, seorang praktisi yang sudah berlisensi dalam pengajaran membaca alqur'an menggunakan buku Ummi.

Pada dasarnya kegiatan pelatihan dan pendampingan untuk memberantas buta huruf hijaiyyah di Kelurahan Ketawanggede ini sangat mendapat respon positif dari semua pihak, baik dari Kelurahan, Pengurus atau Pengelola TPQ At-Taubah, terutama ibu-ibu rumah tangga peserta kegiatan ini. Para peserta menunjukkan antusiasme dalam mengikuti kegiatan ini. Namun karena jadwal kegiatan pelatihan dan pendampingan ini bertepatan dengan beberapa 
kegiatan setempat yang banyak melibatkan peserta dari kalangan ibu rumah tangga, seperti perayaan 'Idul Adha, peringatan hari Kemerdekaan Republik Indonesia ke-74, dan sebagainya, maka kehadiran dan keikutsertaan ibu-ibu rumah tangga kurang maksimal. Banyak dari para peserta yang menjadi panitia kegiatan, banyak pula yang menjadi peserta lomba.

Hasil kegiatan pelatihan dan pendampingan melek huruf hijaiyyah bagi ibuibu rumah tangga yang terselenggara atas kerja sama Lembaga Penelitian dan Pengabdian kepada Masyarakat (LP2M) UIN Maulana Malik Ibrahim Malang dan Kecamatan Lowokwaru yang berlangsung cukup singkat ini dapat diuraikan secara singkat pada Tabel 1.

Berdasarkan data-data yang dideskripsikan, yaitu tentang fokus dan tujuan kegiatan, peserta kegiatan, praktik pelaksanaan kegiatan, jadwal dan materi kegiatan, kendala, serta hasil dari kegiatan ini, maka dapat kita katakan bahwa kegiatan pengabdian kepada masyarakat yang berlokasi di RT/RW 03/03 Kelurahan Ketawanggede, Kecamatan Lowokwaru, Kota Malang ini telah berjalan sesuai jadwal yang ditetapkan dan dapat dikatakan cukup berhasil sesuai dengan tujuan pengabdian.

Dalam prakteknya, peserta ada yang menggunakan buku atau modul Ummi, juz 'amma, atau bahkan Al-Qur'an. Untuk memberi penekanan terhadap makhraj huruf tertentu, kami menggunakan buku atau modul Ummi, selanjutnya untuk memberi penekanan latihan tentang kaidah tajwid tertentu, kami memanfaatkan atau merujuk kepada buku Ummi. Dengan kata lain, kegiatan pelatihan dan pendampingan membaca Al-Qur'an ini menggunakan metode eklektik atau gabungan dari beberapa metode yang diambil bagian kelebihannya.

Tabel 1. Hasil kegiatan

\begin{tabular}{ccc}
\hline Kelompok & Kondisi Awal & Kondisi setelah \\
Peserta & Pelatihan dan \\
& Pendampingan
\end{tabular}

\begin{tabular}{|c|c|c|}
\hline 1 & $\begin{array}{l}\text { Belum } \\
\text { mengenal } \\
\text { huruf hijaiyah }\end{array}$ & $\begin{array}{l}\text { Mulai mengenal } \\
\text { dan hafal huruf } \\
\text { hijaiyah, dapat } \\
\text { membaca } \\
\text { rangkaian huruf- } \\
\text { huruf terpisah }\end{array}$ \\
\hline 2 & $\begin{array}{l}\text { Sudah sedikit } \\
\text { mengenal } \\
\text { huruf } \\
\text { hijaiyyah, } \\
\text { namun banyak } \\
\text { keliru dalam } \\
\text { pelafalannya }\end{array}$ & $\begin{array}{l}\text { Mulai dapat } \\
\text { membedakan bunyi } \\
\text { huruf-huruf yang } \\
\text { mirip atau } \\
\text { berdekatan, seperti: } \\
ث-\omega, د-j \text {, w } \\
ش, \varepsilon-I \text {, dan } \\
\text { sebagainya. }\end{array}$ \\
\hline 3 & $\begin{array}{l}\text { Sudah dapat } \\
\text { membaca } \\
\text { huruf-huruf } \\
\text { terpisah dan } \\
\text { bersambung, } \\
\text { sudah hafal } \\
\text { beberapa } \\
\text { surat-surat } \\
\text { pendek, } \\
\text { namun perlu } \\
\text { koreksi dalam } \\
\text { makharijul } \\
\text { huruf dan } \\
\text { hokum bacaan } \\
\text { tajwidnya }\end{array}$ & $\begin{array}{l}\text { Lebih berkurang } \\
\text { kekeliruan dalam } \\
\text { makharijul huruf } \\
\text { dan hokum bacaan } \\
\text { tajwid praktis, } \\
\text { seperti hokum nun } \\
\text { sukun dan tanwin, } \\
\text { bacaan ghunnah, } \\
\text { beberapa bacaan } \\
\text { mad (tabi'I, wajib } \\
\text { muttasil, jaiz } \\
\text { munfasil, mad } \\
\text { iwadh, mad layyin } \\
\text { dan sebagainya). }\end{array}$ \\
\hline
\end{tabular}

Belajar al-qur'an untuk orang dewasa sangatlah berbeda dengan anak-anak, dari segi waktu, metode dan juga prosesnya. Sangat komplek yang harus diperhatikan dalam mengajar orang dewasa untuk belajar membaca al-qur'an. Dari segi waktu, mengajar orang tua tidaklah dengan jangka waktu yang panjang dengan berbagai kendala kesibukan dan lainlain. Dari segi metode, orang tua biasanya senang belajar dengan cara pada zamannya yaitu secara klasikal yang lebih memperhatikan kebutuhannya serta memikirkan kendalanya dengan disodorkan solusi-solusi ringan agar kegiatan belajar mengaji tetap berjalan. Dari segi proses orang tua lebih senang dengan fokus satusatu diajari belajar mengaji tidak secara berjamaah, hal ini dikarenakan dengan factor penghambat misalnya mulut yang sudah kaku untuk meniru karena sudah terlalu lama belum belajar mengaji al-qur'an dan masih banyak lagi. 
Kegiatan Pengabdian kepada Masyarakat yang berjudul 'Metode Sorogan sebagai Model Pemberantasan Buta Huruf Hijaiyyah bagi Ibu-ibu Rumah Tangga di Kelurahan Ketawanggede Kecamatan Lowokwaru Kota Malang' mendapat respon positif baik dari pihak kecamatan, kelurahan, pengasuh TPQ, maupun para peserta yang terdiri dari ibu-ibu rumah tangga. Para peserta merasakan langsung manfaat dari kegiatan ini, yaitu dengan peningkatan kualitas kemampuan bacaan Al-Qur'an mereka. Mereka merasa lebih percaya diri karena dapat mengajari anak-anak mereka di rumah mengenal dan membaca huruf hijaiyyah.

Oleh karena itu, kami sebagai tim pengabdi sangat terbuka dan bersedia apabila suatu saat dimintai bantuan berupa pelatihan atau pendampingan serupa dengan harapan semakin erat hubungan baik yang terjalin antara pihak UIN Maliki dengan pihak kecamatan, ataupun hubungan personal antar tim pengabdi dengan para peserta atau subyek dampingan.

\section{PENUTUP}

\section{Kesimpulan}

Berdasarkan kegiatan pengabdian kepada masyarakat yang telah dilaksanakan, dapat ditarik beberapa kesimpulan sebagai berikut:

1. Program pelatihan dan pendampingan melek huruf hijaiyyah dengan target peserta ibu-ibu rumah tangga sangat penting dilakukan karena ibu merupakan sosok terdekat dengan putra-putrinya yang mempunyai lebih banyak kesempatan untuk mengajarkan banyak hal kepada putra putrinya, termasuk mengajarkan mengaji,

2. Program kegiatan UIN Mengabdi 2019 dengan fokus permasalahan pemberantasan buta huruf hijaiyyah bagi ibu-ibu rumah tangga di Kelurahan Ketawanggede, Kecamatan Lowokwaru, Kota Malang telah terlaksana sesuai jadwal,

3. Kendati ditemui beberapa kendala dalam pelaksanaannya, kegiatan ini dapat dinilai relative berhasil dengan beberapa indikator yang diuraikan di atas.

\section{Saran}

Program kegiatan pengabdian kepada masyarakat mendatang hendaknya dilakukan dengan perencanaan yang matang dalam hal administrasi dan keuangan, sehingga tim pengabdi dapat lebih focus pada kegiatan pengabdian,

Hendaknya dilakukan kegiatan lanjutan atas kegiatan ini dengan mempertimbangkan waktu pelaksanaan yang tepat dan durasi yang lebih lama sehingga pelatihan dan pendampingan yang diberikan kepada peserta lebih intensif dan lebih berhasil.

\section{DAFTAR PUSTAKA}

Abdullah, Imam bin Ismail al-Bukhari. Shohih Bukhari juz VI, (Beirut: Darul Fikri, 1981)

Afdal, "Implementasi Metode Ummi dalam Meningkatkan Kemampuan Membaca Al-Qur'an Siswa kelas III B Ibnu Khaldun Sd Al-Firdaus Islamic School Samarinda", Jurnal Pendas Mahakam, 1 (Juni, 2016)

Amrullah, Fahmi. Ilmu Al-Qur'an untuk Pemula. (Jakarta: CV Artha Rivera, 2008)

Armai Arief, Pengantar Ilmu Dan Metodologi Pendidikan Islam. (Jakarta: Ciputat Pers, 2002)

Djamarah, Syaiful Bahri Pola Komunikasi Orang Tua dan Anak Dalam Keluarga, (Jakarta: Rineka Cipta, 2004)

Federspie, Howard, Kajian Al-Qur'an di Indonesia. (Bandung: Mizan Anggota IKAPI,1996)

Hafidz, Muhammad Nur abdul Mendidik Anak Bersama Rasulullah SAW. 
Terjemahan Kuswandani dkk (Bandung: Al-Bayan, 1997)

Jajaluddin, Ibu Madrasah Umat: Fungsi dan Peran kaum Ibu sebgai Pendidik Kodrati, (Jakarta: Kalam Mulia, 2016)

Muljono Damopolli, Pesantren Modern Immim (Pencetak Muslim Modern), (Jakarta: Raja Wali Pers, 2011)

Salman Nashif Ad-Dahduh, Sahabat Bertanya Rasulullah Menjawab, (Jakarta: Cendika Sentra Muslim, 2004)

Suprijanto. Pendidikan Orang Dewasa. (Jakarta . PT Bumi Aksara, 2007)

Syarifuddin.Ahmad Mendidik Anak Membaca, Menulis, Dan Mencintai AlQur'an, (Jakarta: Gema Inswani, 2004) 